\title{
A Study of College Students' Reading Behavior and Reading Promotion Strategies in Omnimedia Environment
}

\author{
Jingwu Han ${ }^{1, a}$ \\ ${ }^{1}$ Library, Tonghua Normal University, China \\ adbcy9999@163.com
}

Keywords: composite, Media, reading, promotion.

\begin{abstract}
In this paper, a study of College Students' reading behavior and reading promotion strategies in omnimedia environment as the theme, this paper analyzes this issue from four aspects. First of all, the article analyzes the characteristics of the media environment of College Students under the composite reading from four aspects. Secondly, this article from the three aspects of the complex problems of college students reading may exist in all media environment are summarized, then, from three different dimensions of the media environment of college students composite reading behavior has made several suggestions, finally, discusses the Promotion Countermeasures of College Students' reading the whole composite media environment from three aspects. Hope this research can inspire and help for the relevant experts and scholars.
\end{abstract}

\section{Introduction}

The omnimedia is in a text, graphics, images, animation, sound and video on a variety of media means based on the different forms of media (print media, television media, broadcast media, network media, mobile phone media etc.) between fusion, a new communication form have the qualitative change after.

\section{The characteristics of College Students' compound reading in the all media environment}

\subsection{The coexistence of old and new reading channels}

The way of reading from the traditional paper media, electronic channels to today's diverse way of reading, students can come into contact with modern information more and more. Although now gradually began to weaken the media in all media era of influence, but whether it is in the habit of reading, reading or in the mass base, all still occupies an important position. At the same time, mobile phone reading, Internet channels, digital reading media also gradually into the campus life, love by 90 students.

\subsection{The selective enhancement of reading}

The traditional media, the main content of college students to read professional knowledge, and in all media, mainly oriented to college students began focusing on entertainment, life, news and so on, the choice of content increases, promoted students' reading behavior of the composite directivity, which also indirectly promote college students' reading the change of behavior patterns.

\subsection{The degree of reading has changed}

With the increasing volume of information, college students' reading level of information is rapidly changing, on the one hand, the entire media age reading speed has reached a new height, fast browsing information has become the new norm, on the other hand, the pure "rigid" reading has become the past, it is happy. Relaxed, comfortable reading experience. 


\subsection{The process of reading begins simple}

From the fixed place of the original reading, began to change as the place to read, let the students read now everywhere, in the appliance with reading function, the reader can always achieve the process of reading, students in the background of the whole media under the real implementation of the composite reading. Including the main reasons: one is the largest form of broadcasting degree of satisfaction of the audience's sense of hearing, relieve visual fatigue of reading, two is a network, better communication mode to cater to the audience's psychological feelings, enhance reading texture, mobile phone and other mobile terminal three is read completely changed the audience's sense of touch and change the traditional reading feeling.

\section{The possible problems of College Students' compound reading in the all media environment}

\subsection{The utilitarian reading is not conducive to the development of College Students}

Here said the "utilitarian" reading is reading only focus on superficial attention, negative impact of real information transmission biases caused by the lack of system thinking. College students are a special group, values, outlook on life is still in rapid development period, rapid reading fast media time, is likely to have an adverse impact on College students. Therefore, the composite reading to find a way to solve the information. Information on the current situation of hybrid acquired, "utilitarian" reading is affecting many college students, it brings negative effects are gradually emerging.

\subsection{Network security affects the quality of life of College Students}

From the recent exposure of some malignant situation, the entire media age reading environment is not so safe. The network hackers and virus threats still affects the normal operation of the campus reflects in: one is to read the contents of college students are black, violence and other undesirable content, but also the lack of adequate external the power to eliminate and prevent the risk, two students have information disclosure in the interactive information, such as the "threat of adverse events on Campus -" great students' life, three of college students have a unique population characteristics, such as less social experience, poor awareness, knowledge and technology of higher degree, so, which caused the students prone to be attacked in the process of reading.

\subsection{Composite with reading way influence the reading effect}

Under the new era, the composite reading behavior of college students and the composite reading promotion has not been effective scientific guidance and management, in the process of reading the time wasting and low efficiency, one reason of which the most important is the composite reading the matching mode unreasonable. Specifically including: one is the composite reading selection the structure is not reasonable, no maximum effectiveness of compound two is the use of the advantages of reading, reading of the compound is not scientific, not better become students to help the development of the three, is the lack of reading promotion composite have become the correct demonstration, other readers.

\section{Some suggestions for the all media environment of college students reading behavior of the composite}

\subsection{Suggestions for individual students}

With the rapid development of the era of reading media, individual students to have a clear plan for their reading activities: first, by establishing their own reading concept, set the good feasibility of reading plan for yourself. Make reading become a scientific and healthy development way, become rich themselves, others, value orientation. The benefit of society at the same time, reading program through the development of actual landing, will record the read bit, become a powerful weapon for personal growth and development; second, to develop good reading habits, cultivate good reading 
literacy. Not only to the time of different media under the way of reading thinking finer, but also take she's reading literacy for their continuous grinding, can record card, mind map and other tools to enhance the ability to control the reading habits; third, through reading atmosphere transformation, actively promote the quality of reading. From time to time from their own situation, to find effective ways for their reading, by changing the form of reading activities, form a good reading atmosphere under the multimedia environment, influence and drive around with people who enjoy reading from the positive energy, and in turn, improve the overall quality of their reading.

\subsection{Suggestions for the Organization Department}

To promote the "good background of national reading" in the country, the government should put the entire media age college students reading as the focus of attention and help the field. First of all, should appoint special departments to lead the implementation of the organization, as an important part of the cultural construction. To straighten out the relevant departments to coordinate the work of rules, strengthen the division of responsibilities the competent department, carry out the theme of the campaign, focus on solving a number of bad events of public opinion, establish a number of typical concentration has good demonstration effect of advanced; secondly, to do a good job of preferential policies, to ensure adequate funding. To set up special funds to invest in the channel, or the establishment of special funds to promote the maturity of composite reading experience and practice in reading, environmental facilities, and ancillary equipment, increase investment, and actively mobilize the enthusiasm, realize the strong Security forces; thirdly, to let the community are strongly concerned about the composite reading, concerned about college students, to give the necessary support in the key point, the full realization of cultivation and curing students composite reading behavior and habits.

\subsection{Suggestions for the construction of colleges and Universities}

The university is an important carrier of college life, learning and growth, combined with their own actual situation to discuss countermeasures, to professional, grade, sub categories, effective guidance and supervision of the whole process of the composite reading of students step by step. In general, there are the following suggestions: first, give full play to the library the role, especially to the composite development trend of the library construction, operation management, "digital". This requires the school to guide students to correct group screening of network information, enhance navigation search function in building their own website, professional database to speed up the construction of high quality; second, to strengthen the campus network security communication channels, safety, construction safety and other aspects of personal information maintenance, help students in the composite reading process, reduce the adverse factors on the network at the maximum Third, school;

\section{The promotion strategy of College Students' compound reading in the all media environment}

\subsection{Tap new forms of promotion and constantly enrich the theme of promotional activities}

Either the school or the community, to borrow the trend of the development of information, to do specific work. Not only can promote the full use of school their own unique advantages and resources, can also spread angle and extending in the direction of innovative, in college students, the whole society formed a strong range of information attention public opinion atmosphere. For example: the school can use the community and the theme of day, to carry out various forms of theme and thematic activities in the interior, let the composite reading become the growth of college students cultural propaganda weapon; government departments can be combined with a city, cultural festivals and other opportunities to college students as the forerunner, driven by the local people the composite reading intention; all kinds of social groups and local universities can depth cooperation, the folk art 
forms and ingenious way of reading and college students' composite Used together, to do public service through into the community, love and other activities, will implement the "unity".

\subsection{Interact with each other to develop personalized reading and promotion service}

Should be closely combined with the psychological characteristics of college students, and actively play the role of the media in the media, personal development, diversification of the media, to form a new development model of personalized habits. On the one hand, the school can use their own resources and information, to carry out targeted investigation and reading promotion service, using a timely feedback mechanism micro-blog reader comments or suggestions, and strive to build in the network environment of library reading promotion service brand; on the other hand, conditional iconic locations and point to try to promote the establishment of exclusive services, such as the national 5A level scenic spots or the bustling commercial district, through the use of mobile phone, the mobile terminal equipment of PAD electronic the one-stop resource retrieval, navigation and full text acquisition, realizes the function of self-service mobile services at any time and Journal of electronic books, newspapers, online Retrieval and reading.

\subsection{To provide social interaction and promote interactive reading}

From the analysis of the current development trend of big data, the future promotion of composite reading of college students in our country cannot do without the interactive communication channels. Through interactive communication with social networking, let reading is no longer the only individual acts, but a group of reading behavior we are familiar with the micro-blog model. WeChat, all kinds of communication software, has been in the information transmission on a huge "hourglass body".

\section{Summary}

In the current all-media environment, the power of reading gets increasing attention. Just as the culture promotion, the reading promotion is one of the driving means of the development of information society, and the function of the library to reading promotion is irreplaceable. Based on the present situation of the development of information technology, library should make aggressive innovation and explore more ways of reading promotion that are suitable for the university students, so as to realize the effective combination of traditional book reading and modern digital reading. Library should also consistently improve service for students' reading, and as well as their reading experience and knowledge accomplishment, so that the development a reading society can be promoted.

\section{References}

[1] Ding Yudong, New strategy of reading promotion under the background of multimedia resources construction, Journal of Library Science, 2016.

[2] Han Wei, Research on reading behavior and reading promotion in Digital Times, China National Exhibition, 2016.

[3] Zhao Mingxia, Study on the impact of new media on the reading behavior of Contemporary College Students, The Journal of the Library Science in Jiangxi,2010.

[4] Ni Jia, Reading promotion and service innovation of University Library Management, Journal of Hunan University of Arts and Science, 2016.

[5] Tian Zhongfang, Analysis and Countermeasures of students' reading behavior in Higher Vocational Medical Colleges, Journal of Qinghai Normal University (Philosophy and Social Sciences Edition), 2011. 